\title{
PERSEPSI MAHASISWA TERHADAP PELAKSANAAN PERKULIAHAN PENDIDIKAN GURU MATEMATIKA DAN IPA UNGGULAN DI PROGRAM STUDI PENDIDIKAN KIMIA FKIP UNIVERSITAS RIAU
}

\author{
Herdini*, Erviyeni, Betty Holiwarni \\ Program Studi Pendidikan Kimia FKIP Universitas Riau Pekanbaru \\ Email :herdinimunir@yahoo.co.id
}

\begin{abstract}
Purpose of this study was to know student's perception about preparation and implementation of lectures Mathematics and Science Teacher Education Featured at Chemistry Department of Education Faculty Riau University. The research carried out on students of Chemistry Department, the population was all students who follow the Mathematics and Science Teacher Education Featured program, and have followed courses presented for the program. The whole population was used as a sample (total sample), amounting to 60 students, consisting of a student of 2011/2012, 2012/2013 and 2013/2014 classes (18, 20 and 22 students). Data have been collected using a questionnaire, and then analyzed descriptively, begins with a questionnaire scoring in stages, specify the interval value to obtain a value category, and specify the percentage. The results showed that $81,66 \%$ of students had a good understanding of the program that followed, $16.67 \%$ adequate, and $1.67 \%$ less understood. $86.67 \%$ of students felt that the program was beneficial, 8:33\% felt pretty, and 5\% of students felt less useful. In terms of feasibility program, $73.34 \%$ of students stated good, $15 \%$ said enough, and $11.66 \%$ said less well, while from the commitment and ability of lecturers $53.35 \%$ of the students stated well, 35\% fairly categories, and 11, 67\% said less.
\end{abstract}

Keywords :Mathematics and Science teacher Education Featyred Program, Student's Perception

\begin{abstract}
Abstrak
Penelitian ini bertujuan untuk mengetahui persepsi mahasiswa terhadap persiapan dan pelaksanaan perkuliahan PGMIPA Unggulan di Program Studi Pendidikan kimia FKIP Universitas Riau. Penelitian dilakukan terhadap mahasiswa Pendidikan Kimia, dengan populasi seluruh mahasiswa yang mengikuti Program PGMIPA Unggulan, dan telah mengikuti mata kuliah yang disajikan untuk program tersebut. Seluruh populasi digunakan sebagai sampel (sampel total) yang berjumlah 60 orang, terdiri dari mahasiswa angkatan 2011/2012, 2012/2013 dan angkatan 2013/2014 (18, 20 dan 22 orang mahasiswa). Data hasil penelitian dikumpulkan dengan menggunakan angket, dan kemudian dianalisis secara deskriptif,dimulai dengan penskoran angket secara bertingkat, menentukan interval nilai untuk memperoleh kategori nilai, dan menentukan persentase. Hasil penelitian menunjukkan bahwa $81,66 \%$ mahasiswa sudah memahami dengan baik program yang diikutinya, $16,67 \%$ cukup, dan $1,67 \%$ kurang paham. $86,67 \%$ mahasiswa merasakan bahwa program tersebut bermanfaat, $8.33 \%$ merasakan cukup, dan 5\% mahasiswa merasa kurang bermanfaat. Dari segi keterlaksanaan program, 73,34\% mahasiswa menyatakan baik, $15 \%$ menyatakan cukup, dan $11,66 \%$ menyatakan urang baik, sedangkan dari sisi komitmen dan kemampuan dosen, 53,35\% mahasiswa menyatakan baik, 35\% kategori cukup, dan 11,67\% menyatakan kurang.
\end{abstract}

Kata Kunci : Program PGMIPA Unggulan, Persepsi Mahasiswa 


\section{PENDAHULUAN}

Mutu pendidikan sangat ditentukan oleh mutu proses pembelajaran yang dilakukan. Pembelajaran merupakan suatu proses yang mengandung serangkaian perbuatan pendidik dan peserta didik atas dasar hubungan timbal balik yang berlangsung dalam situasi edukatif untuk mencapai tujuan pembelajaran (Usman,dkk., 2000). Proses pembelajaran yang berkembang di kelas umumnya ditentukan oleh peran pendidik dan peserta didik sebagai individu-individu yang terlibat langsung di dalam proses pembelajaran. Cara mengajar yang baik merupakan kunci dan syarat bagi peserta untuk dapat belajar dengan baik (Trianto. 2007). Seorang pendidik harus mempunyai wawasan yang luas dan kemampuan yang tinggi untuk dapat melaksanakan proses pembelajaran dengan baik dan berdampak positif terhadap peserta didik dan lingkungan. Disamping individu pendidik yang bersangkutan berkewajiban meningkatkan kemampuannya, instansi yang menghasilkan pendidik itu sendiri juga mempunyai tanggungjawab yang tinggi terhadap kualitas calon pendidik yang dihasilkannya.

Pendidikan Guru Matematika dan Ilmu Pengetahuan Alam Unggulan (PGMIPA-U) merupakan salah satu program pengembangan yang dicanangkan Direktorat Jendral Perguruan Tinggi (DIKTI) di setiap LPTK mulai tahun 2007, dalam rangka mempersiapkan guru-guru MIPA yang unggul dan mampu mengajar di sekolah bertaraf internasional atau dalam dua bahasa, selain menghasilkan tenaga pendidik lokal.Jurusan PMIPA FKIP Universitas Riau termasuk salah satu LPTK yang memperoleh hibah untuk melaksanakan program tersebut semenjak tahun ajaran 2011/2012.

Pembelajaran untuk PGMIPAU di FKIP Universitas Riau dilaksanakan oleh tenaga pengajar yang dibekali kemampuan bahasa Inggeris secukupnya kalau tidak mau dikatakan kurang. Untuk kelangsungan program DIKTI tersebut tenaga pengajar program pengembangan ini merasa perlu mencari tahu bagaimana persepsi mahasiswa yang telah mengikuti perkuliahan unggulan selama tiga semester. Persepsi mahasiswa terhadap pelaksanaan pembelajaran merupakan prinsip utama yang harus dikondisikan dalam proses pembelajaran. Banyak usaha yang dilakukan untuk mempertahankan persepsi positif mahasiswa terhadap suatu pelaksanaan pembelajaran guna meningkatkan keberhasilan mahasiswa antara lain penguasaan materi, menerapkan model inovatif dan mempersiapkan perangkat pembelajaran yang bermutu.

Program Studi Pendidikan Kimia merupakan salah satu program studi pelaksana 
PGMIPAU yang melaksanakan perkuliahan dalam dua bahasa yaitu berbahasa Indonesia dan.berbahasa Inggeris(bilingual). Dengan segala keterbatasan yang ada, kadang-kadang kurang maksimal dalam pengelolaan mahasiswa walaupun sebagai dosen selalu berusaha untuk dapat tampil maksimal dalam perkuliahan. Oleh karena itu untuk mengembangkan PGMIPAU kedepan perlu diketahui bagaimana persepsi mahasiswa tentang Fasilitas, pelaksanaan dan arah pengembangan yang dibutuhkan mahasiswa, sehingga diharapkan dapat meningkatkan kualitas proses pembelajaran serta kajian keilmuan yang bermanfaat bagi pengembangan diri mahasiswa maupun dosen, karena persepsi merupakan salah satu aspek psikologis yang penting bagi manusia dalam merespon kehadiran berbagai aspek dan gejala di sekitarnya

Persepsi mengandung pengertian yang sangat luas, menyangkut intern dan ekstern. Berbagai ahli telah memberikan definisi yang beragam tentang persepsi, walaupun pada prinsipnya mengandung makna yang sama. Menurut Kamus Besar Bahasa Indonesia, persepsi adalah tanggapan (penerimaan) langsung dari sesuatu. Proses seseorang mengetahui beberapa hal melalui panca inderanya. Persepsi adalah kemampuan otak dalam menerjemahkan stimulus atau proses untuk menerjemahkan stimulus yang masuk ke dalam alat indera manusia(Sugihartono, dkk., 2007). Persepsi manusia terdapat perbedaan sudut pandang dalam penginderaan. Ada yang mempersepsikan sesuatu itu baik atau persepsi yang positif maupun persepsi negatif yang akan mempengaruhi tindakan manusia yang tampak atau nyata.

Persepsi merupakan suatu proses Pengorganisasian, penginterpretasian terhadap stimulus yang diterima oleh organisme atau individu sehingga menjadi sesuatu yang berarti, dan merupakan aktivitas yang integrated dalam diri individu (Walgito, B., 2004). Respon sebagai akibat dari persepsi dapat diambil oleh individu dengan berbagai macam bentuk. Stimulus mana yang akan mendapatkan respon dari individu tergantung pada perhatian individu yang bersangkutan. Berdasarkan hal tersebut, perasaan, kemampuan berfikir, pengalaman-pengalaman yang dimiliki individu tidak sama, maka persepsi masing-masing individu terhadap suatu stimulus mungkin akan berbeda antara individu satu dengan individu lain. Setiap orang mempunyai kecenderungan dalam melihat benda yang sama dengan cara yang berbeda. Perbedaan tersebut bisa dipengaruhi oleh banyak faktor, diantaranya adalah pengetahuan, pengalaman dan sudut pandangnya.

Persepsi juga berhubungan dengan cara pandang seseorang terhadap suatu objek 
tertentu dengan cara yang berbeda-beda dengan menggunakan alat indera yang dimiliki, kemudian berusaha untuk menafsirkannya. Persepsi baik positif maupun negatif ibarat file yang sudah tersimpan rapi di dalam alam pikiran bawah sadar kita. File itu akan segera muncul ketika ada stimulus yang memicunya, ada kejadian yang membukanya.

Persepsi dinyatakan juga sebagai pengamatan tentang objek, peristiwa atau hubungan-hubungan yang diperoleh dengan menyimpulkan informasi dan menafsirkan pesan(Rakhmat, J., 2003). Sedangkan, Suharman (2006) menyatakan: bahwa persepsi merupakan suatu proses menginterpretasikan atau menafsir informasi yang diperoleh melalui sistem alat indera manusia. Menurutnya ada tiga aspek di dalam persepsi yang dianggap relevan dengan kognisi manusia, yaitu pencatatan indera, pengenalan pola, dan perhatian. Dari penjelasan di atas dapat ditarik suatu kesamaan pendapat bahwa persepsi merupakan suatu proses yang dimulai dari penglihatan hingga terbentuk tanggapan yang terjadi dalam diri individu sehingga individu sadar akan segala sesuatu dalam lingkungannya melalui indera-indera yang dimilikinya.

Proses terjadinya persepsi berlangsung saat seseorang menerima stimulus dari dunia luar yang ditangkap oleh organ-organ bantunya, kemudian masuk ke dalam otak. Di dalamnya terjadi proses berfikir yang pada akhirnya terwujud dalam sebuah pemahaman. Proses yang terjadi dalam otak atau dalam pusat kesadaran inilah yang disebut sebagai proses psikologis (Sarwono, 2007). Proses ini merupakan proses terakhir dari persepsi dan merupakan persepsi sebenarnya. Respon sebagai akibat dari persepsi dapat diambil oleh individu dalam berbagai macam bentuk.

Persepsi dipengaruhi oleh dua faktor, yaitu faktor internal dan eksternal.Faktor internal meliputi faktor biologis, sosiopsikologis, dan faktor fungsional, sedangkan faktor eksternal meliputi gerakan, intensitas stimulus, kebaruan dan perulangan [6].Jika ditinjau dari segi psikologis, menurut Wade (2007), faktor-faktor yang dapat mempengaruhi persepsi antara lain adalah : a) Kebutuhan, b) kepercayaan, c) emosi, dan d) ekspektasi. Walaupun persepsit terlihat sebagai kemampuan bawaan karena dipengaruhi oleh alat indra masing-masing individu, tidak berarti orang-orang yang ratarata memiliki indra yang sama mempersepsikan dunia dengan cara yang sama pula.

Berdasarkan berbagai pernyataan yang telah dikemukakan di atas perumusan masalah dalam penelitian ini adalah :Bagaimanakah persepsi mahasiswa terhadap pelaksanaan pembelajaran secara bilingual di program studi pendidikan kimia?. 
Tujuan penelitian adalah untuk mengetahui persepsi mahasiswa terhadap pelaksanaan perkuliahan secara bilingual di program studi pendidikan kimia untuk pengembangan PGMIPA Kimia Unggulan

Hasil penelitian diharapkan dapat memberikan gambaran persepsi mahasiswa terhadap pelaksanaan pembelajaran sehingga memberikan arah bagi program studi pendidikan kimia dalam menindaklanjuti perkuliahan PGMIPA-U masa yang akan datang. Bagi dosen dapat memperluas kemampuan dalam menguasai kelas sesuai karakter mahasiswa, materi pembelajaran guna membantu mengatasi kelemahan dosen maupun mahasiswa dalam melaksanakan pembelajaran.

\section{METODE PENELITIAN.}

Penelitian ini dilaksanakan di Program Studi Pendidikan Kimiai FKIP Unuversitas Riau, tahun akdemis 2013/2014. Pengambilan data dilakukan pada bulan Juni sampai November 2013.

Populasi dalam penelitian ini adalah seluruh mahasiswa program studi pendidikan kimia FKIP Universitas Riau yang mengikuti Program PGMIPA-U, dan telah mengambil mata kuliah yang disajikan untuk program PGMIPA-U semester gasal dan genap di Program Studi Kimia FKIP Universitas Riau., sedangkan teknik pengambilan sampel adalah total sampling, yaitu dengan menjadikan semua populasi menjadi sampel, dengan kata lain semua mahasiswa kimia yang menjadi populasi, dijadikan sampel, dengan jumlah 60 orang yang terdiri dari angkatan 2011/2012 18 orang, angkatan 2012/2013 20 orang, dan angkatan 2013/2014 22 0rang.

Parameter yang diukur dalam penelitian ini adalah : persepsi mahasiswa terhadap persiapan dan pelaksanaan perkuliahan program PGMIPA-U di Program Studi Pendidikan Kimia FKIP Universitas Riau.Data hasil penelitian dikumpulkan dengan menggunakan teknik observasi.Observasi dilakukan dengan angket.Angket yang dimaksud adalah angket persepsi mahasiswa terhadap persiapan dan pelaksanaan Progran PGMIPA-Unggulan di Program Studi Pendidikan Kimia FKIP Universitas Riau.Pemyataan dalam angket dinilai dengan skor penilaian skala bertingkat (rating scala) yang dimodifikasi dari Arikunto, S. (2006) sebagai berikut:
1. Sangat setuju $(\mathrm{SS})=$ Skor 4
2. Setuju $(\mathrm{S})=$ Skor 3
3. Kurang Setuju (KS) - Skor 2
4. Tidak setuju (TS) - Skor 1 
Setelah diketahui skor masing - masing item , maka selanjutnya digunakan rumussebagai berikut: $M=Z F x / N$

Keterangan : $\mathrm{M}=$ Rata-rata yang ingin dicari, $Z F x=$ Jumlah dari hasil perkalian antara masing - masing skor dengan frekuensinya.

$\mathrm{N}=$ Banyak individu (Arikunto, S., 2006)

Selanjutnya dimasukkan kedalam interval nilai sebagai berikut:

Tabel 1. Interval Nilai dan Kategori Hasil Pengolahan Angket

\begin{tabular}{cc}
\hline Interval Nilai & Kategori \\
\hline $3,7-4$ & Baik sekali \\
\hline $2,7-3,69$ & Baik \\
\hline $2,0-2,69$ & Cukup \\
\hline$<1,99$ & Kurang \\
\hline
\end{tabular}

(Arikunto, S., 2006)

\section{HASIL DAN PEMBAHASAN}

Data yang disajikan dalam penelitian ini merupakan data hasil pengolahan angket yang disebarkan kepada mahasiswa kimia yang mengikuti program PGMIP-U/Bilingual yang berjumlah 60 orang. Hasil pengolahan angket dikelompokkan ke dalam beberapa bahagian, sesuai aspek yang diinginkan

\section{Pemahaman Mahasiswa terhadap Program PGMIPA-U/Bilingual}

Mahasiswa Kimia FKIP Universitas Riau sebahagian besar (81.66\%) sudah paham tentang program PGMIPA-U/Bilingual yang diselenggarakan, hanya sekitar $1.67 \%$ saja yang tidak paham, sedangkan sisanya $16.67 \%$ termasuk kategori cukup paham (Tabel 2).

Tabel 2.Kategori Pemahaman Mahasiswa Kimia Terhadap Program PGMIPA-U /Bilingual.

\begin{tabular}{cccc}
\hline NO. & Kategori & Jumlah Mahasiswa & Persentase \\
\hline 1 & Baik Sekali & 17 & $28.33 \%$ \\
\hline 2 & Baik & 32 & $53.33 \%$ \\
\hline 3 & Cukup & 10 & $16.67 \%$ \\
\hline 4 & Kurang & 1 & $1.67 \%$ \\
\hline
\end{tabular}

\section{Manfaat program PGMIPA-U/Bilingual bagi Mahasiswa}

Data mengenai manfaat Program PGMIPA-U/Bilingual bag mahasiswa dapat dilhat pada Tabel 3 . 
Tabel 3. Kategori Manfaat Program PGMIPA-U/Bilingual bagi Mahasiswa Kimia

\begin{tabular}{cccc}
\hline NO. & Kategori & Jumlah Mahasiswa & Persentase \\
\hline 1 & Baik Sekali & 15 & $25 \%$ \\
\hline 2 & Baik & 37 & $61.67 \%$ \\
\hline 3 & Cukup & 5 & $8.33 \%$ \\
\hline 4 & Kurang & 3 & $5 \%$ \\
\hline
\end{tabular}

Hasil pengolahan data pada Tabel 3 menunjukkan bahwa $86.67 \%$ mahasiswa merasakan manfaat dari program PGMIPA-U yang diadakan di Program Studi Kimia FKIP Universitas Riau, sebahagian kecil mahasiswa kurang merasakan manfaat dari program tersebut. Tabel 2 dan 3 yang menjaring pemahaman dan manfaat program PGMIPA-U di program studi kimia, menunjukkan bahwa sebahagian besar mahasiswa yang mengikuti program tersebut sudah paham dan mengerti manfaat dari program tersebut. Hal ini disebabkan karena sebelum program ini dilaksanakan, program studi telah memberikan sosialisasi kepada seluruh mahasiswa, dan dosen-dosen yang terlibat dengan program PGMIPA-U ini, juga memberikan arahan kepada mahasiswa sebelum pelaksanaan perkuliahan.

\section{Keterlaksanaan Program PGMIPA-U di Program Studi Kimia FKIP Universitas} Riau

Persepsi Mahasiswa terhadap keterlaksanaan program PGMIPA-U/Bilingual di Program Studi Kimia dapat dilihat pada Tabel 4.

Tabel 4. Kategori Keterlaksanaan Program PGMIPA-U di Program Studi Kimia

\begin{tabular}{cccc}
\hline NO. & Kategori & Jumlah Mahasiswa & Persentase \\
\hline 1 & Baik Sekali & 10 & $16.67 \%$ \\
\hline 2 & Baik & 34 & $56.67 \%$ \\
\hline 3 & Cukup & 9 & $15 \%$ \\
\hline 4 & Kurang & 7 & $11.66 \%$ \\
\hline
\end{tabular}

Berdasarkan Tabel 4 dapat dijelaskan bahwa pelalsanaan program PGMIPA-U di Program Studi Kimia dapat dikategorikan baik ( 73.34\% dari jumlah mahasiswa),namun masih ada 11, 66\% mahasiswa yang menyatakan pelaksanaan program tersebut terkategori kurang baik, dan $15 \%$ cukup baik.

\section{Kemampuan dan Komitmen dosen dalam Melaksanakan Program}

Angket yang disebarkan kepada mahasiswa juga menjaring kemampuan dan komitmen dosen dalam melaksanakan program PGMIPA-U yang telah direncanakan sebelumnya. Kategori hasil yang diperoleh dapat dilihat pada Tabel 5. 
Tabel 5. Kategori Kemampuan dan Komitmen Dosen dalam Pelaksanaan Program PGMIPA-U/Bilingual di Program Studi Kimia

\begin{tabular}{cccc}
\hline NO. & Kategori & Jumlah Mahasiswa & Persentase \\
\hline 1 & Baik Sekali & 5 & $8.33 \%$ \\
\hline 2 & Baik & 27 & $45 \%$ \\
\hline 3 & Cukup & 21 & $35 \%$ \\
\hline 4 & Kurang & 7 & $11.66 \%$ \\
\hline
\end{tabular}

Tabel 5 menunjukkan kategori persepsi mahasiswa terhadap kemampuan dan komotmen dosen dalam pelaksanaan program PGMIPA-U. Dari tabel terlihat kemampuan dan komitmen dosen dalam kategori baik hanya 53.33\%, sedangkan kategori cukup 35\%, dan kategori kurang 11.67\%.Dalam hal ini masih sangat diperlukan peningkatan kemampuan dan komitmen dosen dalam berbahasa asing, terutama bahasa Inggeris.

\section{KESIMPULAN}

Berdasarkan Hasil dan Pembahasan yang telah diuraikan di atas, dapat disimpulkan halhal sebagai berikut :

1. Persepsi mahasiswa terhadap pelaksanaan program PGMIPA-u/bilingual di Program Studi Kimia FKIP UR tergolong kategori baik, dilihat dari pemahaman mahasiswa terhadap program PGMIPA-U, manfaat dan keterlaksanaan program.

2. Dari segi kemampuan dan Komitmen Dosen hanya 53,33\% yang terkategori baik

\section{SARAN}

Berdasarkan kesimpulan di atas disarankan terutama kepada dosen-dosen pengampu mata kuliah PGMIPA-U untuk lebih meningkatakan kualitas pembelajaran, terutama dalam penggunaan bahasa asing/inggeris.

\section{Ucapan Terima Ksih}

Ucapan terima kasih disampaikan kepada pengelola program PGMIPA Unggulan FKIP Universitas Riau yang telah mendanai penelitian ini. 


\section{DAFTAR PUSTAKA}

Arikunto,S., 2006,Metode Statistik Pendidikan, Tarsito Bandung

Depdiknas, 2003, Kurikulum 2004 SMA, Pedoman Khusus Pengembangan Silabus dan Penilaian Mata Pelajaran Kimia Jakarta

Rakhmat J., 2003, Psikologi Komunikasi, Bandung, Penerbit Remaja Rosda Karya

Sarwono, 2007, Psikologi Remaja, Jakarta, PT Raja Grafindo Persada

Sugihartono, 2007, Psikologi Pendidikan, Yogyakarta, UNY Press

Suharman, 2005, Psikologi Kognitif, Surabaya, Srikandi

Trianto.2007, Model-model Pembelajaran Inovatif Berorientasi kontruktivisme.Prestasi Pustaka Publisher. Jakarta

Usman MU dan Setiawati, L, 2000Menjadi Guru Profesional, Bandung, Remaja Rosda Karya

Hardani, W. \& Ali, B., 2007, Psikologi edisi ke 9, jilid 1, Jakarta, Erlangga

Walgito B., 2004,Pengantar Psikologi Umum, Yogyakarta, Andi Offset 